\title{
Neurogenic and Neuroendocrine Effects of Goldfish Pheromones
}

\author{
Yu-Wen Chung-Davidson, Christopher Benjamin Rees, Mara Beth Bryan, and Weiming Li \\ Department of Fisheries and Wildlife, Michigan State University, East Lansing, Michigan 48824
}

Goldfish (Carassius auratus) use reproductive hormones as endocrine signals to synchronize sexual behavior with gamete maturation and as exogenous signals (pheromones) to mediate spawning interactions between conspecifics. We examined the differential effects of two hormonal pheromones, prostaglandin $\mathrm{F}_{2 \alpha}\left(\mathrm{PGF}_{2 \alpha}\right)$ and 17 $\alpha, 20 \beta$-dihydroxy-4-pregnen-3-one (17,20 $\beta$-P) on neurogenesis, neurotransmission, and neuronal activities, and on plasma androstenedione $(\mathrm{AD})$ levels. Exposure to waterborne $\mathrm{PGF}_{2 \alpha}$ induced a multitude of changes in male goldfish brain. Histological examination indicated an increase in the number of dividing cells in male diencephalon $(p<0.05$, Kruskal-Wallis test). Real-time quantitative PCR tests showed elevated levels of transcripts for the salmon gonadotropinreleasing hormone $(\mathrm{GnRH})$ in the male telencephalon and cerebellum $(p<0.005$, one-way ANOVA) and for ChAT (choline acetyltransferase) in the male vagal lobe and the brainstem underneath the vagal lobe $\left(p<0.05\right.$, one-way ANOVA). Therefore, PGF $_{2 \alpha}$ seemed to modulate male brain plasticity that coincided with behavioral changes during spawning season. Exposure to waterborne 17,20 $\beta$-P, however, increased circulatory levels of immunoreactive AD in males and the transcripts of androgen receptor and cGnRH-II (chicken-II $\mathrm{GnRH}$ ) in the female cerebellum ( $p<0.05$, one-way ANOVA). $\mathrm{PGF}_{2 \alpha}$ and $17,20 \beta$-P thereby seemed to act through distinct pathways to elicit different responses in the neuroendocrine system. This is the first finding that links a specific pheromone molecule $\left(\mathrm{PGF}_{2 \alpha}\right)$ to neurogenesis in a vertebrate animal.

Key words: Carassius auratus; $17 \alpha, 20 \beta$-dihydroxy-4-pregnen-3-one; prostaglandin $\mathrm{F}_{2 \alpha}$; androstenedione; neurogenesis; $\mathrm{GnRH}$

\section{Introduction}

Adult neurogenesis occurs in many species including both vertebrates and invertebrates. In the subventricular zone of adult mammalian forebrain, a cell population retains the potential to generate new neurons destined for the olfactory bulb (Goldman, 1997, 1998; García-Verdugo et al., 1998; Luskin, 1998). New neurons are also produced year-round in the dentate gyrus throughout the life of the individual (Kempermann et al., 1998; Gould et al., 1999; Conover et al., 2000; Lim et al., 2000). In songbirds, widespread telencephalic adult neurogenesis adds new neurons to the high vocal center. Neuronal turnover in the high vocal center plays a role in the modification of perceptual memories or motor programs for song production in these animals (AlvarezBuylla and Kirn, 1997; Goldman, 1998). Seasonally variable neurogenesis and recruitment has also been demonstrated in the hippocampus of avian brains (Barnea and Nottebohm, 1994,

\footnotetext{
Received July 30, 2008; revised 0ct. 30, 2008; accepted Nov. 28, 2008.

This work was supported by the Great Lakes Fishery Commission and National Science Foundation Grant IOB 0517491. We thank Drs. D. Close, H. Wu, S.-S. Yun, and Z. Zhang for their help with sample collection. We thank Dr A. P. Scott for his generous gift of the anti-androstenedione antibody. We thank Dr. N. E. Stacey for helpful discussions in experimental designs. We thank the anonymous reviewers for valuable suggestions to this manuscript. We thank Dr. P. J. Davidson and S. Chang for proofreading this manuscript.

Correspondence should be addressed to Dr. Weiming Li, Department of Fisheries and Wildlife, Michigan State University, 100 Giltner Hall, East Lansing, Ml 48824. E-mail: liweim@msu.edu.

C. B. Rees's present address: Great Lakes WATER Institute, United States Department of Agriculture/Agricultural Research Service, 600 East Greenfield Avenue, Milwaukee, WI 53204.

M. B. Bryan's present address: Energy Biosciences Institute, University of California, 130 Calvin Laboratory, MC 5230, Berkeley, CA 94720.

DOI:10.1523/JNEUROSCI.3589-08.2008

Copyright $\odot 2008$ Society for Neuroscience $\quad$ 0270-6474/08/2814492-08\$15.00/0
}

1996; Tramontin and Brenowitz, 2000). In reptiles, adult neurogenesis results in new growth of several telencephalic areas and appears to be seasonally regulated (Ramirez et al., 1997). In decapod crustaceans, persistent neurogenesis among olfactory projection neurons is a common principle that shapes the adult brain, indicating a remarkable degree of lifelong structural plasticity (Harzsch et al., 1999). In some insects, persistent neurogenesis occurs in the mushroom bodies, which are brain structures involved in learning and memory and considered as functional analogues of the hippocampus (Cayre et al., 2002). However, this phenomenon is absent in other insects and therefore cannot be seen as a common feature in all insect brains (Fahrbach et al., 1995; Gronenberg et al., 1996).

Adult neurogenesis in both vertebrates and invertebrates appears to be regulated by internal factors such as hormones, neurotransmitters, and growth factors, and by external factors such as environmental cues (Scotto Lomassese et al., 2000; Cayre et al., 2002). Pheromones are a class of environmental cues that are known to exert profound effects in insect brains (Grozinger et al., 2003, 2007; Alaux and Robinson, 2007; Beggs et al., 2007; Grozinger and Robinson, 2007; Vergoz et al., 2007). In mice, odors from soiled bedding of dominant males have been shown to stimulate neurogenesis in the olfactory bulb and the hippocampus of adult females (Mak et al., 2007). However, no specific pheromone molecules have been linked to induction of neurogenesis in vertebrates.

The goldfish (Carassius auratus) pheromone system contains at least two known pheromone molecules, prostaglandin $\mathrm{F}_{2 \alpha}$ 
Table 1. Neurogenesis in goldfish brain

\begin{tabular}{|c|c|c|c|c|}
\hline Brain area & Control $(n=8)$ & $\mathrm{L}-\operatorname{Ser}(n=5)$ & $\mathrm{PGF}_{2 \alpha}(n=4)$ & $17,20 \beta-\mathrm{P}(n=7)$ \\
\hline Olfactory bulb & $0.0 \pm 0.0^{a}$ & $0.2 \pm 0.2$ & $0.4 \pm 0.4$ & $0.0 \pm 0.0^{a}$ \\
\hline Telencephalon & $0.3 \pm 0.2$ & $0.4 \pm 0.2$ & $0.3 \pm 0.3$ & $0.0 \pm 0.0^{a}$ \\
\hline Midbrain & $0.6 \pm 0.3$ & $0.7 \pm 0.3$ & $0.8 \pm 0.5$ & $0.8 \pm 0.3$ \\
\hline Vulvela & $0.1 \pm 0.1$ & $0.4 \pm 0.2$ & $0.5 \pm 0.5$ & $0.4 \pm 0.3$ \\
\hline Brainstem under vulvela & $0.9 \pm 0.3$ & $2.7 \pm 1.2$ & $8.9 \pm 6.1$ & $2.2 \pm 1.0$ \\
\hline Cerebellum & $0.3 \pm 0.2$ & $0.7 \pm 0.3$ & $2.4 \pm 1.5$ & $4.0 \pm 2.1$ \\
\hline Brainstem under cerebellum & $15.4 \pm 6.9$ & $28.8 \pm 15.7$ & $72.6 \pm 49.6$ & $47.6 \pm 23.9$ \\
\hline Facial lobe & $1.4 \pm 0.8$ & $0.9 \pm 0.6$ & $6.4 \pm 6.0$ & $1.1 \pm 0.8$ \\
\hline Brainstem under facial lobe & $5.0 \pm 2.0$ & $8.4 \pm 7.3$ & $32.7 \pm 19.0$ & $16.3 \pm 6.3$ \\
\hline Glossopharyngeal lobe & $0.3 \pm 0.2$ & $0.2 \pm 0.2$ & $1.4 \pm 1.1$ & $0.7 \pm 0.4$ \\
\hline Brainstem under glossopharyngeal lobe & $3.1 \pm 1.5$ & $2.6 \pm 1.6$ & $10.4 \pm 9.1$ & $8.5 \pm 3.1$ \\
\hline Vagal lobe & $6.3 \pm 3.5$ & $2.9 \pm 2.1$ & $35.0 \pm 19.9$ & $27.4 \pm 17.2$ \\
\hline Brainstem under vagal lobe & $14.1 \pm 7.4$ & $3.6 \pm 2.0$ & $25.6 \pm 14.4$ & $29.1 \pm 10.8$ \\
\hline
\end{tabular}

Data are presented as number of dividing cells/section (mean \pm SEM). The same individuals were used for measurements in different brain regions.

${ }^{a} \mathrm{No}$ dividing cells were found in these brain regions. However, because of the small sample size, the result was not statistically significant.

$\left(\mathrm{PGF}_{2 \alpha}\right)$ and $17 \alpha, 20 \beta$-dihydroxy-4-pregnen-3-one (17,20 $\beta$-P), detected by distinct sets of olfactory receptor neurons as tested by electroolfactogram (Sorensen et al., 1989). This system allows us to examine the mechanisms by which different pheromone molecules modulate brain plasticity and the neuroendocrine system. In this report, we examined whether the sex pheromones $\mathrm{PGF}_{2 \alpha}$ and $17,20 \beta$-P affected neurogenesis, neuronal activities, and neurotransmitters in goldfish brain as well as plasma androstenedione $(\mathrm{AD})$ concentrations.

\section{Materials and Methods}

Animals. Spawning-stage goldfish (total length, 4-6 inches) were acquired from Ozark Fisheries and transported to Michigan State University. Goldfish were placed in an $800 \mathrm{~L}$ flow-through tank (Frigid Units), acclimated to $15^{\circ} \mathrm{C}$, and fed daily with Tetrafin Tropical Flakes for $7 \mathrm{~d}$. After the initial acclimation at $15^{\circ} \mathrm{C}(12 \mathrm{~h}$ light/dark cycle), goldfish were divided by sex into two separate tanks. Animal handling procedures were approved by the Institutional Committee on Animal Use and Care of Michigan State University.

One week before pheromone treatment, goldfish were randomly assigned to flow-through aquaria $(0.5 \mathrm{~L} / \mathrm{min})$ containing $40 \mathrm{~L}$ of aerated water heated to $18^{\circ} \mathrm{C}$. Three goldfish of the same sex were placed into each aquarium. Feeding was continued for a period of $3 \mathrm{~d}$ while goldfish were acclimated to $18^{\circ} \mathrm{C}$. Two days before pheromone exposure, fish were taken off feed to eliminate nonexperimental food odorants from the testing aquarium. Pheromone treatment was specified in each experiment and administered every $20 \mathrm{~min}$ to each aquarium to maintain appropriate concentrations.

Experiment 1: Treatment for examining the effect of pheromonal exposure on neurogenesis in male goldfish. Twenty-four male spawning goldfish were treated with ethanol ( $318 \mu \mathrm{l} / \mathrm{L}), 10^{-6} \mathrm{M} \mathrm{L}$-serine (L-Ser) (SigmaAldrich), $2 \times 10^{-10} \mathrm{M} \mathrm{PGF}_{2 \alpha}$ (Sigma-Aldrich), or $2 \times 10^{-10} \mathrm{M} 17,20 \beta-\mathrm{P}$ (Sigma-Aldrich) for $4 \mathrm{~h}$. The treatment was timed so that it ended at dawn (typical spawning time for goldfish) (Partridge et al., 1976). The $4 \mathrm{~h}$ treatment time corresponds to the period of biological release of $\mathrm{PGF}_{2 \alpha}$ in ovulating female goldfish (Stacey, 2003). Ethanol (vehicle) was used to make up the stock solution. L-Ser served as an odor control because L-amino acids have been established as important feeding stimulants for teleost fish (Atema et al., 1980; Carr, 1982). They have also been suggested to serve as nonreproductive social cues in goldfish as well as other fish (Hara et al., 1984; Saglio and Fauconneau, 1985). The concentration of $\mathrm{PGF}_{2 \alpha}$ or $17,20 \beta-\mathrm{P}$ was chosen according to Sorensen et al. (1988, 1989, 1990).

Immediately before pheromone exposure, fish were intraperitoneally injected with $25 \mathrm{mg} / \mathrm{ml}$ 5-bromo-2'-deoxyuridine (BrdU) (Sigma-Aldrich; dissolved in $0.9 \%$ saline, $0.01 \mathrm{ml} / \mathrm{g}$ body weight). Immediately after the pheromone treatment, fish were euthanized with $0.05 \%$ MS222 (3-aminobenzoic acid ethyl ester) (Sigma-Aldrich). Brain tissues were removed, fixed in $4 \%$ paraformaldehyde (in $0.1 \mathrm{~m}$ phosphate buffer, $\mathrm{pH}$
7.4) overnight, and transferred to $20 \%$ sucrose. Tissues were then embedded in OCT mounting media and kept at $-80^{\circ} \mathrm{C}$ until use.

Immunohistochemistry. Brain tissues were sectioned into $20 \mu \mathrm{m}$ slices using a Leica CM1850 cryostat. Sections were mounted onto SuperFrost Plus microslides (VWR Scientific) and immunostained for antigens of interest. Negative controls for immunocytochemistry (deprived of the primary antibody of interest) were performed simultaneously in every immunostaining experiment.

To double stain the brain tissue for BrdU and an additional antigen, sections were rinsed three times in Tris-buffered saline (TBS) $(50 \mathrm{~mm}$ Tris, $150 \mathrm{~mm} \mathrm{NaCl}$, pH 7.2) for $5 \mathrm{~min}$ between each step of the protocol. All reagents were diluted with TBS/0.5\% Triton X-100 according to the manufacturer's instructions unless mentioned otherwise. Sections were incubated in $0.3 \%$ hydrogen peroxide (diluted with TBS) for $10 \mathrm{~min}$, followed by $2 \mathrm{~N} \mathrm{HCl}$ for $30 \mathrm{~min}$. Sections were blocked by normal horse serum (Vectastain ABC kit; Vector Laboratories) for 15 min and incubated in the mixture of antibody for BrdU (1:1000; Sigma-Aldrich) and normal horse serum (Vector Laboratories) overnight at $4^{\circ} \mathrm{C}$. Sections were then incubated in biotinylated secondary antibody (horse antimouse IgG; Vector Laboratories) for $2 \mathrm{~h}$ at room temperature, followed by $\mathrm{ABC}$ solution (Vector Laboratories) for $2 \mathrm{~h}$ at room temperature. Finally, sections were reacted with 3,3'-diaminobenzidine/nickel chloride (DAB substrate kit) (Vector Laboratories) for $15 \mathrm{~min}$. After the immunocytochemistry (ICC) procedure for BrdU detection, sections were processed for ICC for another antigen. Immunocytochemistry for the second antigen(s) was performed following the same steps described above using appropriate normal serum and secondary antibody, but using DAB (Vector Laboratories) as the chromagen to show different color (brown) from the first set (black) of the ICC. The concentrations for the antibodies used were as follows: 1:100 mouse-anti- $\alpha$-internexin (Millipore), 1:1000 mouse-anti-S100 $\beta$ (Sigma-Aldrich), and $1 \mu \mathrm{g} / \mathrm{ml}$ rabbitanti-HuD (Millipore). Dividing cells with minimum cytoplasm and a pronounced granulated nucleus were counted in different brain area using unbiased stereological method described by Chung-Davidson et al. (2008).

Experiment 2: Effect of pheromonal treatment on the mRNA levels of androgen receptor, neuronal activation markers, and neurotransmitters in goldfish brain. Seventy-two spawning goldfish were treated with ethanol $(318 \mu \mathrm{l} / \mathrm{L}), 10^{-6} \mathrm{M} \mathrm{L}_{-}$Ser, $2 \times 10^{-10} \mathrm{M} \mathrm{PGF}_{2 \alpha}$, or $2 \times 10^{-10} \mathrm{M} 17,20 \beta-\mathrm{P}$ for $4 \mathrm{~h}$ and anesthetized as described for experiment 1 . Brains were removed from the cranium, separated into four parts (telencephalon, midbrain/diencephalon, cerebellum/brainstem underneath cerebellum, and vagal lobe/brainstem underneath vagal lobe) (supplemental Fig. 1, available at www.jneurosci.org as supplemental material), snap frozen in liquid nitrogen, and stored at $-80^{\circ} \mathrm{C}$ before use.

Real-time quantitative PCR. Real-time quantitative PCR (RTQ-PCR) followed the procedure described by Rees and Li (2004). Briefly, total RNA was extracted using TRIzol reagent (Invitrogen), treated with TURBO DNA-free kit (Applied Biosystems), and diluted to $100 \mathrm{ng} / \mu \mathrm{l}$. 
RNA samples were then reverse transcribed into cDNA using M-MLV reverse transcriptase (Invitrogen) and random hexamers (Promega). RTQ-PCR was performed using the TaqMan MGB system (Applied Biosystems). Each reaction consisted of $2 \mu \mathrm{l}(5 \mathrm{ng} / \mu \mathrm{l}) \mathrm{cDNA}, 8 \mu \mathrm{l}$ of TaqMan Universal PCR master mix, $900 \mathrm{~nm}$ each forward and reverse primers, and $250 \mathrm{~nm}$ TaqMan MGB probe. Amplification plots were analyzed on an ABI 7900 real-time PCR thermal cycler (Michigan State University Research Technology Support Facility, East Lansing, MI). Synthetic oligos were used as standards and ran on the sample plate. Standards were PCR-amplified using the primers for RTQPCR, purified with MinElute PCR purification kit (Qiagen), and serially diluted (10-fold) into $10^{10}-10^{3}$ molecules/2 $\mu \mathrm{l}$ solutions. The sequences for standards, primers, and TaqMan MGB probe for each mRNA are listed in the supplemental material (available at www.jneurosci.org). $18 \mathrm{~S}$ ribosomal RNA was used as an internal standard and was confirmed not to have changes in expression levels among treatment groups.

Experiment 3: Effect of pheromonal exposure on plasma $A D$ concentrations in goldfish. One hundred sixty-eight spawning goldfish were treated with ethanol $(318 \mu \mathrm{l} / \mathrm{L}), 10^{-6} \mathrm{M} \mathrm{L}-\mathrm{Ser}$,

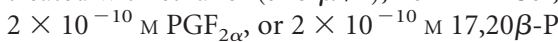
for $4 \mathrm{~h}$ and anesthetized as described for experiment 1 . Body length and weight were recorded as well as the presence or absence of expressible milt. Blood was obtained from the caudal vein using heparinized syringes, held at $4^{\circ} \mathrm{C}$ for 20 $\mathrm{min}$, and centrifuged at $1000 \times \mathrm{g}$ for $20 \mathrm{~min}$. The plasma was removed and stored at $-20^{\circ} \mathrm{C}$ before use.

Quantification of $A D$ in goldfish plasma. Plasma samples were diluted 1:50 in buffer (50 mu sodium phosphate, $\mathrm{pH} 7.4,137 \mathrm{~mm} \mathrm{NaCl}$, $0.40 \mathrm{~mm}$ EDTA, and $0.77 \mathrm{~mm}$ sodium azide). To inactivate sex steroid binding proteins, the diluted plasma samples were incubated at $60^{\circ} \mathrm{C}$ for $30 \mathrm{~min}$ and centrifuged at $2000 \times g$ for 15 $\min$. The supernatant was then tested using radioimmunoassay for $\mathrm{AD}$ [similar to Scott et al. (1980)]. Antiserum raised against AD was generously provided by Dr. A. P. Scott (Centre for Environment, Fisheries and Aquaculture Science, Weymouth, UK) and tritiated $\mathrm{AD}$ was purchased from GE Healthcare. The assay buffer consisted of $50 \mathrm{~mm}$ sodium phosphate, $\mathrm{pH} 7.4,0.2 \%$ bovine serum albumin, $137 \mathrm{~mm}$ $\mathrm{NaCl}, 0.40 \mathrm{~mm}$ EDTA, and $0.77 \mathrm{~mm}$ sodium azide. Nine standards were made up in duplicate over the range $500-1.95 \mathrm{pg} / 100 \mu \mathrm{l}$ per tube (twofold serial dilution). The tubes containing unknowns also had a volume of $100 \mu \mathrm{l}$. Binding reagent was made by adding radiolabel and antisera to $20 \mathrm{ml}$ of assay buffer in amounts such that, when $100 \mu \mathrm{l}$ was dispensed to all tubes, each tube contained 5000 disintegrations per minute (dpm). In the absence of any standard, $50 \%$ of the radiolabel was bound to the antisera. Blank tubes, to which no antibody was added, and tubes necessary to determine the total maximum $\mathrm{dpm}$ counts, were also included in the assay. All tubes were incubated overnight at $4^{\circ} \mathrm{C}$. The tubes were placed on ice, and $500 \mu \mathrm{l}$ of ice-cold charcoal solution $(50 \mathrm{~mm}$ sodium phosphate, $\mathrm{pH} 7.4,0.1 \%$ gelatin, and $1.0 \%$ dextran-coated charcoal) was added to each tube. The tubes were kept in ice for $15 \mathrm{~min}$, and then centrifuged at $1000 \times \mathrm{g}$ for 12 M, male.
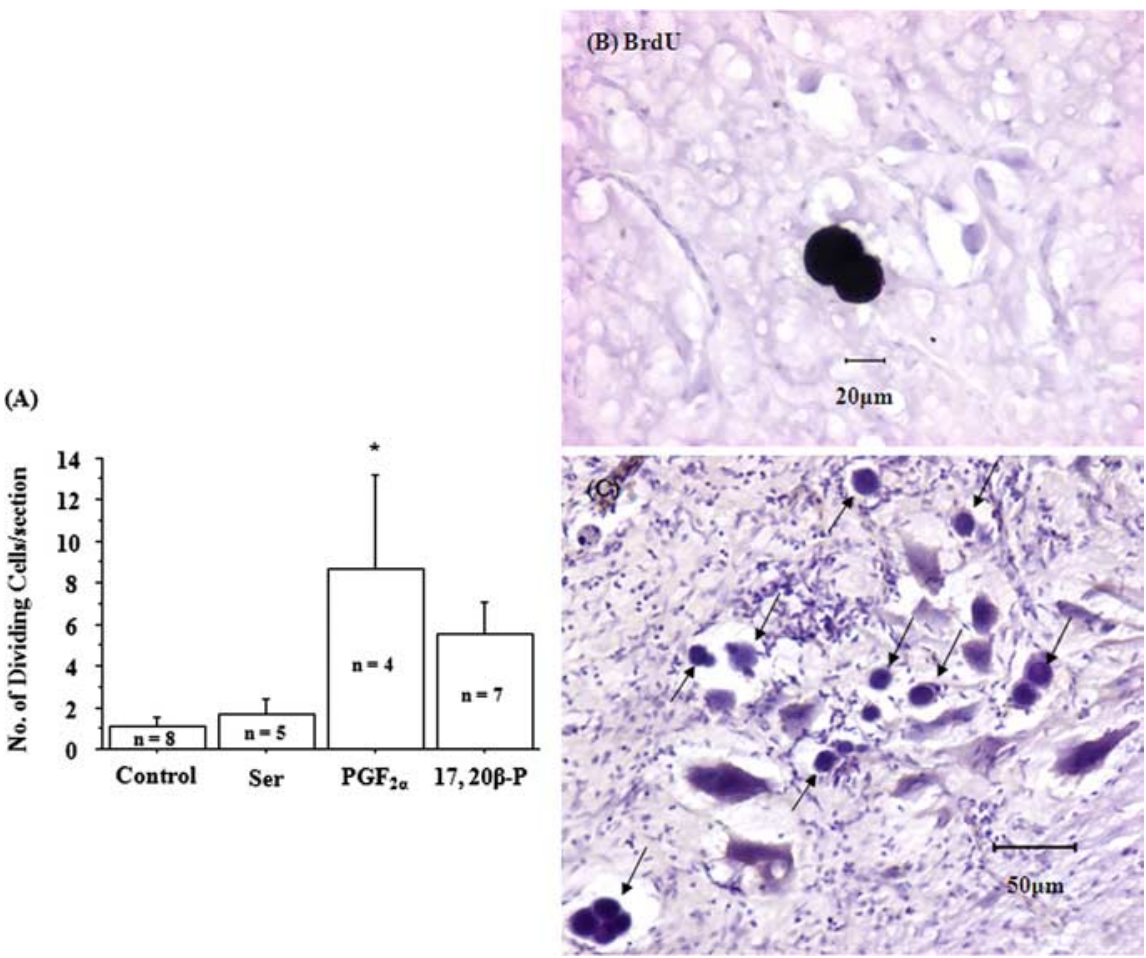

Figure 1. A, Exposure to $2 \times 10^{-10} \mathrm{M} \mathrm{PGF}_{2 \alpha}$ for $4 \mathrm{~h}$ increased the number of dividing cells in the diencephalon of male goldfish. Exposure to vehicle ( $318 \mu \mathrm{l} / \mathrm{L}$ ethanol; control), $10^{-6} \mathrm{M} \mathrm{L}$-serine (Ser), or $2 \times 10^{-10} \mathrm{M} 17,20 \beta$-P had no effect on neurogenesis in male goldfish. The asterisk shows significant difference between control and the treatment group $(p<0.05)$. Error bars indicate SEM. B, BrdU-immunoreactive 2-cells (black stain). C, Dividing cells (black arrows) showed distinct morphological characteristics: minimum cytoplasm with a pronounced granulated nucleus.
(A) Telencephalon sGnRH

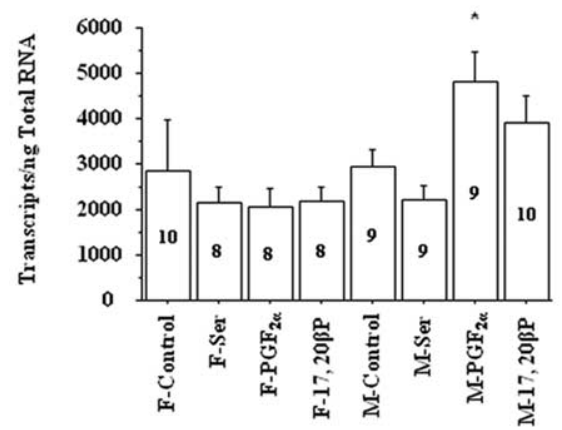

(B) Cer eb ellum sGnRH

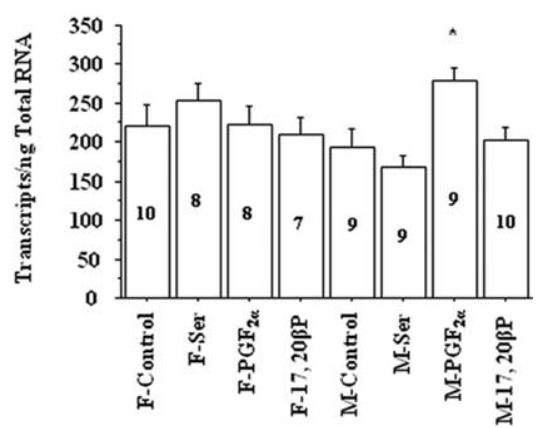

Figure 2. Exposure to $2 \times 10^{-10} \mathrm{MPGF}_{2 \alpha}$ for 4 h increased $\mathrm{G}$ RRH transcripts in the telencephalon and cerebellum of male (M) but not in female (F) goldfish. Exposure to vehicle (318 $\mu \mathrm{l} / \mathrm{L}$ ethanol; control), $10^{-6} \mathrm{M} \mathrm{L}$-serine (Ser), or $2 \times 10^{-10} \mathrm{M} \mathrm{17,20 \beta -P}$ had no effect on sGnRH mRNA levels. The number inside each bar represents sample size $n$ for the corresponding group. The asterisk denotes significant difference between control and the treatment group $(p<0.05)$. Error bars indicate SEM. F, Female;

min. The supernatants were poured into $8 \mathrm{ml}$ scintillation vials, mixed with $6 \mathrm{ml}$ scintillation mixture (Safety-Solve; Research Products International) and counted for dpm using a Beckman LS6500 scintillation counter (Beckman Coulter).

Statistics. Statistical analyses were performed using StatView (SAS Institute). Nonparametric Kruskal-Wallis test was used to compare the number of dividing cells among treatment groups. If there was significant effect by pheromone treatment $(p<0.05$ ), Mann-Whitney $U$ tests were used to examine which group was different from the control. RTQ-PCR data and plasma $\mathrm{AD}$ concentrations were analyzed by one-way ANOVA tests followed by Fisher's PLSD post hoc tests if the ANOVA showed significant effects by pheromone treatment $(p<0.05)$. 


\section{Results}

Neurogenic effects of $\mathrm{PGF}_{2 \alpha}$

As expected for lower vertebrates, dividing cells were found widespread in goldfish brain. Dividing cells showed distinct morphological characteristics: minimum cytoplasm with a pronounced granulated nucleus. The level of neurogenesis in most of the brain was not affected by pheromone treatment (Table 1). However, the number of dividing cells increased in the male diencephalon after PGF $_{2 \alpha}$ exposure (Fig. $1 A$ ). It is noteworthy that no dividing cells were found in the olfactory bulb of the control fish, and the telencephalon of the control and 17,20 $\beta$-P-treated fish. However, because of the small sample size, it was not statistically significant.

$\mathrm{PGF}_{2 \alpha}$ treatment with simultaneous BrdU injection allowed us to identify newly divided cells after pheromone treatment. BrdU-immunoreactive cells were found in the cerebellum as shown by BrdU-immunoreactive 2-cells (Fig. $1 B$ ) and in the midbrain, brainstem, and the spinal cord of male goldfish (supplemental Fig. 2, available at www.jneurosci.org as supplemental material). None of the vehicle- or serine-treated fish brains showed BrdU immunoreactivity (data not shown).

Dividing cells in pheromone-treated male goldfish were mainly found in the motor areas along the brainstem and the spinal cord continuum, such as the secondary gustatory nucleus and nucleus isthmi, the trigeminal motor nucleus, the medial octavolateral nucleus, the facial motor nucleus, the vagal motor nucleus, and the spinal motor nucleus. A few scattered dividing cells were also found in the telencephalon, preoptic area, hypothalamus, optic tectum, vulva cerebellum, and cerebellum (Table 1).

Additional characterization of the dividing cells with immunocytochemistry for various neuronal and glial markers showed that the dividing cells were either neurons ( $\alpha$-internexin or $\mathrm{HuD}$ immunoreactive) or glia (S-100 $\beta$ immunoreactive) (supplemental Fig. 3, available at www.jneurosci.org as supplemental material).

\section{Neuroendocrine effects of $\mathrm{PGF}_{2 \alpha}$}

Exposure to $\mathrm{PGF}_{2 \alpha}$ for $4 \mathrm{~h}$ increased salmon gonadotropinreleasing hormone $(\mathrm{sGnRH})$ mRNA levels in the telencephalon and cerebellum of male but not female goldfish (Fig. 2). Exposure to L-Ser or $17,20 \beta$-P did not affect sGnRH mRNA levels significantly in either sex (Fig. 2). Interestingly, choline acetyltransferase (ChAT) mRNA concentrations also showed increases in the vagal lobe and the brainstem underneath the vagal lobe in male goldfish after $\mathrm{PGF}_{2 \alpha}$ exposure (Fig. 3). Exposure to $\mathrm{PGF}_{2 \alpha}$ had no effect on the mRNA concentrations of androgen receptor (AR), chicken-II gonadotropin-releasing hormone (cGnRH-II), glutamate decarboxylase 3 and 65 (GAD3 and GAD65), neuropeptide Y (NPY), and tyrosine hydroxylase (TH) in goldfish brain of either sex (data not shown).

\section{Effects of 17,20 $-\mathrm{P}$}

Exposure to 17,20 $\beta$-P for $4 \mathrm{~h}$ increased plasma AD levels in male but not in female goldfish (Fig. 4). Exposure to L-Ser or $\mathrm{PGF}_{2 \alpha}$ did not affect the plasma $\mathrm{AD}$ levels of either sex (Fig. 4). Interestingly, only the female cerebellum showed increases in AR and cGnRH-II mRNA concentrations after 17,20 $\beta$-P exposure (Fig. $5)$, and the AR and cGnRH-II transcription levels were highly correlated $(r=0.935 ; p<0.0001)$. Exposure to $17,20 \beta$-P had no effect on the mRNA concentrations of sGnRH, GAD3, GAD65, NPY, and TH in goldfish brains of either sex (data not shown).

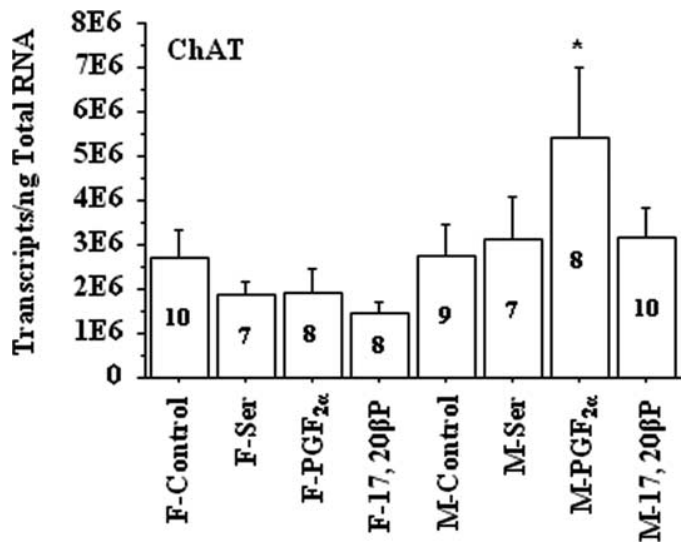

Figure 3. Exposure to $2 \times 10^{-10} \mathrm{MPGF}_{2 \alpha}$ for $4 \mathrm{~h}$ increased ChAT mRNA concentrations in the vagal lobe and the brainstem underneath it in male (M) but not in female (F) goldfish. Exposure to vehicle (318 $\mu \mathrm{l} / \mathrm{L}$ ethanol; control), $10^{-6} \mathrm{M} \mathrm{L}$-serine (Ser), or $2 \times 10^{-10} \mathrm{M}$ $17,20 \beta$-P had no effect on ChAT mRNA levels. The number inside each bar represents sample size $n$ for the corresponding group. The asterisk denotes significant difference between control and the treatment group ( $p<0.05$ ). Error bars indicate SEM. E6, $\times 1,000,000$. F, Female; M, male.

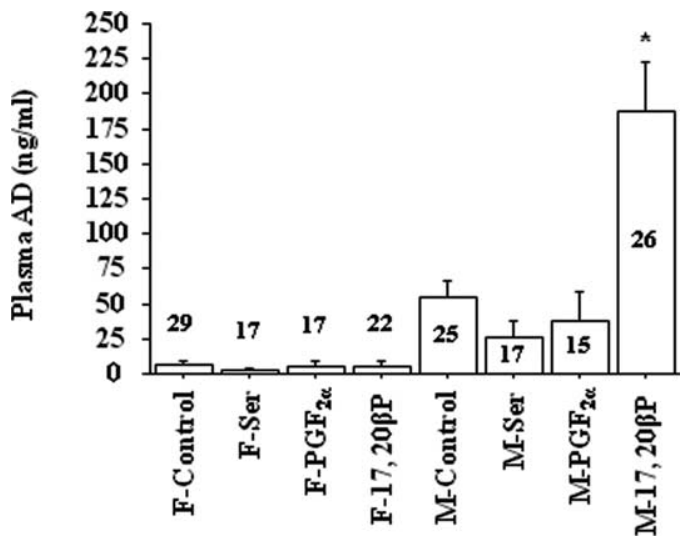

Figure 4. Exposure to $2 \times 10^{-10} \mathrm{M} 17,20 \beta$-P for $4 \mathrm{~h}$ increased $A D$ concentrations in the plasma of male (M) but not in female (F) goldfish, whereas exposure to vehicle (318 $\mu \mathrm{l} / \mathrm{L}$ ethanol; control), $10^{-6} \mathrm{M} \mathrm{L}$-serine (Ser), or $2 \times 10^{-10} \mathrm{M} \mathrm{PGF}_{2 \alpha}$ had no effect on plasma AD levels. The number above or inside each bar represents sample size $n$ for the corresponding group. The asterisk denotes significant difference between control and the treatment group $(p<0.05)$. Error bars indicate SEM. F, Female; M, male.

\section{Sexual dimorphism in goldfish brain immediate-early gene expression}

Neuronal activation markers Fos and Jun (immediate-early genes) showed significant sexual dimorphism in mRNA expression levels in goldfish brains $(p<0.05)$. In general, male brains contained more Fos or Jun mRNA in the midbrain/diencephalon and in the cerebellum than female brains. After L-Ser, $\mathrm{PGF}_{2 \alpha}$, or $17,20 \beta$-P exposure, male goldfish showed decreased Fos mRNA concentrations in the telencephalon and the cerebellum (Fig. 6), whereas Jun mRNA levels did not change after the above treatments (data not shown).

\section{Discussion}

We selected $\mathrm{PGF}_{2 \alpha}$ and $17,20 \beta$-P to examine neurogenesis and neuroendocrine effects of pheromones in goldfish for several reasons. Goldfish use these two molecules both as endogenous signals (hormones) to synchronize spawning behavior with gamete maturation within each individual and as exogenous signals (pheromones) to synchronize sexual interactions between con- 
specifics (Stacey and Sorensen, 2002). At the completion of vitellogenesis, environmental cues, such as temperature changes and the presence of spawning substrates, trigger a gonadotropin (GTH-II) surge in female goldfish. This alters steroidogenesis to favor the production of progestins including 17,20 $\beta$-P (Sorensen et al., 1990; Scott and Sorensen, 1994; Kobayashi et al., 2002; Stacey and Sorensen, 2002). Circulatory $17,20 \beta$-P stimulates oocyte maturation and is subsequently released into the water, serving as a preovulatory pheromone (Sorensen et al., 1990; Scott and Sorensen, 1994; Kobayashi et al., 2002; Stacey and Sorensen, 2002). Waterborne $17,20 \beta$-P stimulates arousal behaviors and GTH-II release in males, which in turn stimulates milt (sperm and seminal fluid) production (Stacey and Sorensen, 1986, 2002; Dulka et al., 1987).

At the time of ovulation, female goldfish oviducts synthesize and secrete $\mathrm{PGF}_{2 \alpha}$ that induces reproductive behaviors (Stacey and Peter, 1979; Sorensen et al., 1988). $\mathrm{PGF}_{2 \alpha}$ and its metabolites (mainly 15keto-PGF $2 \alpha$ ) are also released into water as postovulatory pheromones that induce male spawning behavior and further increase male GTH-II and sperm production (Sorensen et al., 1988, 1989; Sorensen and Goetz, 1993). Therefore, $\mathrm{PGF}_{2 \alpha}$ also plays a dual role as a hormone and a pheromone, synchronizing male and female sexual behaviors in goldfish (Stacey, 1987).

We found that exposure to waterborne $\mathrm{PGF}_{2 \alpha}$ increased neurogenesis and $\mathrm{sGnRH}$ and ChAT mRNA concentrations in male goldfish brain. $\mathrm{PGF}_{2 \alpha}$ seemed to modulate brain plasticity associated with behavioral changes during spawning season via the neuroendocrine (sGnRH) and motor (ChAT) components of the pheromone-reproductive system. The addition of new neurons to the brainstem motor area may enable a structural reorganization of the underlying neural network for spawning behavior. This altered the propensity of goldfish to execute multiple spawning behaviors during the breeding season because goldfish only exhibit overt sexual behavior during spawning season after exposure to waterborne $\mathrm{PGF}_{2 \alpha}$ (Sorensen et al., 1988, 1989; Sorensen and Goetz, 1993). Although the exact mechanisms have yet to be identified, our data strongly link a specific mating pheromone molecule $\left(\mathrm{PGF}_{2 \alpha}\right)$ to adult neurogenesis in a specific brain region (diencephalon) known to be involved in reproduction.

Our data also reveal that $\mathrm{PGF}_{2 \alpha}$ induced neurogenesis in several brain regions outside of telencephalon, including brainstem motor nuclei. This finding confirms previous discoveries in the intensity and regional distribution of adult neurogenesis in different vertebrate taxa. Adult neurogenesis is more widespread and affects more brain regions in nonmammals than in mammals. The restriction of adult neurogenesis to telencephalic areas seems to be a common feature of all amniotic vertebrates (Cayre et al., 2002). In contrast, adult neurogenesis is observed in the olfactory bulb, dorsal telencephalon, optic tectum, cerebellum, and the brainstem in fish (Zupanc, 2006). Neurons born in adult-

\section{(B) cGnRH-II}

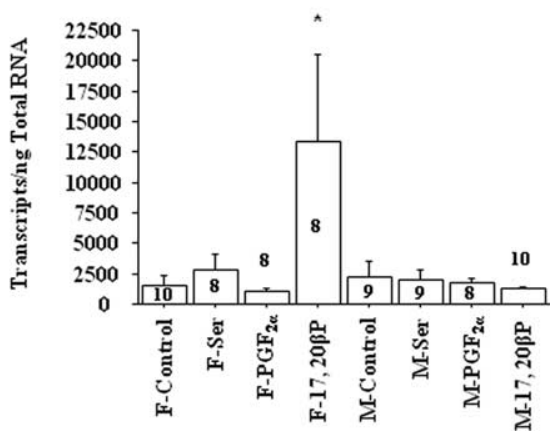

Figure 5. Exposure to $2 \times 10^{-10} \mathrm{M} 17,20 \beta$-P for $4 \mathrm{~h}$ increased $\mathrm{AR}$ and $\mathrm{CGnRH}-\mathrm{Il} \mathrm{mRNA}$ concentrations in the cerebellum of corresponding group. The asterisk denotes significant difference between control and the treatment group $(p<0.05)$. Error bars

Figure 6. Exposure to $10^{-6} \mathrm{M} \mathrm{L}$-serine (Ser), $2 \times 10^{-10} \mathrm{M} \mathrm{PGF}_{2 \alpha^{\prime}}$ or $2 \times 10^{-10} \mathrm{M} 17,20 \beta$-P for $4 \mathrm{~h}$ decreased Fos mRNA concentrations in the telencephalon and cerebellum of male $(M)$ but not female (F) goldfish. The number inside each bar represents sample size $n$ for the corresponding group. The asterisk denotes significant difference between control and the treatment group ( $p<0.05$ ). Error bars indicate SEM. F, Female; M, male.

hood have been reported in all the major subdivisions of the lacertilian telencephalon, including the olfactory bulbs (main and accessory), all of the four cortical areas (medial cortex, dorsomedial cortex, dorsal cortex, and lateral cortex), septum, anterior dorsal ventricular ridge, striatum, and nucleus sphericus (López-García et al., 1988; Pérez-Cañellas and García-Verdugo, 1996; Font et al., 1997; Pérez-Cañellas et al., 1997). The cerebellum may also be a site of adult neurogenesis in some reptiles (López-García et al., 1990). Adult neurogenesis has been reported in the hypothalamus of frogs (Chetverukhin and Polenov, 1993; Polenov and Chetverukhin, 1993). Another striking difference between mammals and nonmammals concerns the types of neurons produced in adulthood. In mammals, only microneurons are produced postnatally (Altman and Das, 1965). Many new neurons born in the brain of reptiles and birds are large and some are projecting neurons (Nottebohm, 1985, 1989; López-García et al., 1988; Pérez-Cañellas and García-Verdugo, 1996; PérezCañellas et al., 1997). We also found neurogenesis in many brainstem motor nuclei containing large neurons in goldfish.

Environmental enrichment and voluntary exercise have consistently been shown to increase adult hippocampal neurogenesis and improve spatial learning ability in mammals (Olson et al., 2006). Several environmental factors, such as seasonal variations in temperature and photoperiod, and sensory inputs influence adult neurogenesis (Cayre et al., 2002). Enriched sensorial and 
(A) Pre-Ovulatory

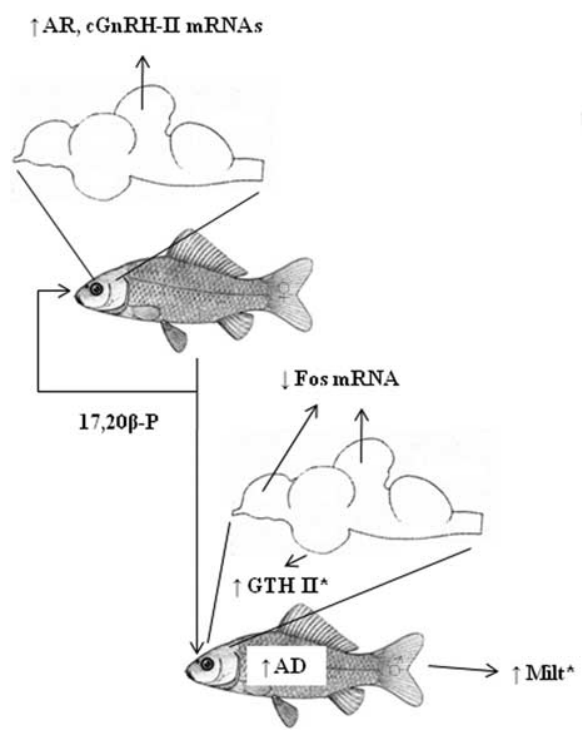

(B) Post-Ovulatory

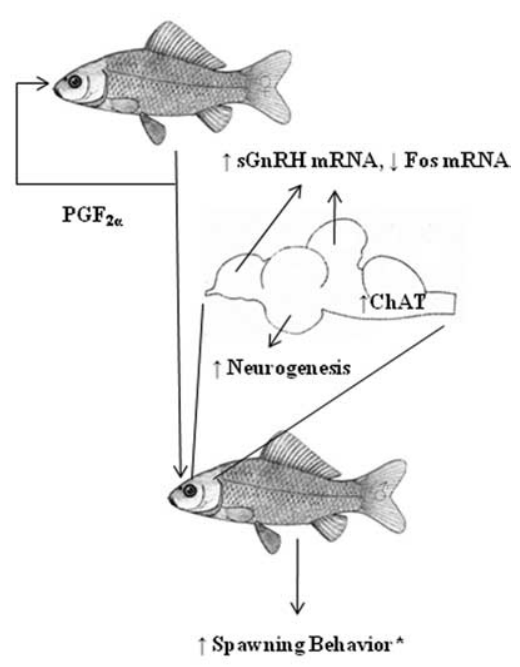

Figure 7. Schematic diagram of goldfish pheromonal communication. *Previous findings in the literature.

This phenomenon was GnRH independent in males because brain sGnRH and cGnRH-II mRNA levels did not change. The increase in plasma $\mathrm{AD}$ would likely result in increased $\mathrm{AD}$ release from male goldfish, because Sorensen et al. (2005) had found that spermiating male goldfish, when sexually aroused by females or their pheromones, release up to $1 \mu \mathrm{g} / \mathrm{h} \mathrm{AD}$. This waterborne 17,20 $\beta$-P-induced plasma $\mathrm{AD}$, when released into water, may advertise the males' own reproductive status to female goldfish and provides reciprocal chemical communication between opposite sexes to synchronize their reproductive cycles. In addition, mature male goldfish could release $\mathrm{AD}$ to trigger agonistic behaviors among males (Poling et al., 2001) and to suppress milt levels in other males (Stacey, 1991; Stacey et al., 2001; Fraser and Stacey, 2002). Hence, AD could act as a bisexual pheromone to inhibit reproduction in the same sex and to stimulate reproduction in the opposite sex.

social environments enhanced neurogenesis in cricket mushroom bodies (Scotto Lomassese et al., 2000), crayfish brain (Sandeman and Sandeman, 2000), and the hippocampus of birds and rodents (Kempermann et al., 1997, 1998; Patel et al., 1997; Gould et al., 1999; van Praag et al., 1999a,b; Ambrogini et al., 2000). Our finding of $\mathrm{PGF}_{2 \alpha}$-induced neurogenesis in goldfish brain suggests that an enriched chemical environment may also promote adult neurogenesis.

Previous studies have indicated that gonadotropin-releasing hormone $(\mathrm{GnRH})$ plays a role in the spawning behavior of female goldfish (Volkoff and Peter, 1999). Chicken GnRH-II is the most conserved form of $\mathrm{GnRH}$ and expressed in neurons of embryonic mesencephalic origin, whereas $\mathrm{sGnRH}$ neurons are mainly distributed in the forebrain from the olfactory system to either the telencephalon or diencephalon (Parhar, 2002). Salmon GnRH, therefore, is the GnRH form that regulates the gonadotroph functions (Scherwood et al., 1997; Yu et al., 1997), whereas the function of cGnRH-II is still elusive (Parhar, 2002). We found an increase in cGnRH-II and AR transcripts in the cerebellum of female goldfish treated with $17,20 \beta-\mathrm{P}$, but not $\mathrm{PGF}_{2 \alpha}$. This suggests that $\mathrm{CGnRH}$-II was associated with the extra-hypothalamicpituitary steroidal pathways of the female reproductive system. Conversely, we found that exposure to $\mathrm{PGF}_{2 \alpha}$ increased sGnRH mRNA concentrations in the telencephalon and the cerebellum of male goldfish. This indicates that sGnRH may be involved in male spawning activity and/or in the process of increasing milt storage (Sorensen et al., 1988, 1989; Zheng and Stacey, 1996, 1997). In both cases, sexual dimorphism in the roles of cGnRH-II and sGnRH in goldfish pheromonal systems was robust. In the future, it will be interesting to determine whether sGnRH plays a role in mediating neurogenesis in the diencephalon of males exposed to $\mathrm{PGF}_{2 \alpha}$.

We found that exposure to waterborne $17,20 \beta$-P increased plasma AD levels in male goldfish. This was consistent with the finding that stimuli from preovulatory and postovulatory females increased plasma concentrations of sex steroids such as testosterone and 17,20 $\beta$-P in males (Kobayashi et al., 1986). The main target for $17,20 \beta-\mathrm{P}$ action seemed to be the steroidsignaling component of the pheromone-reproductive system.
Interestingly, the female cerebellum showed increased AR transcripts after 17,20 $\beta$-P exposure (Fig. 7), which may result in higher sensitivity of female brains to androgens. This may play a role in mediating brain responses to the increased plasma testosterone before the gonadotropin surge at spawning in female goldfish (Kobayashi et al., 1989). However, the actual ligands for the increased androgen receptors in the cerebellum of female goldfish remain unknown. Moreover, waterborne $\mathrm{AD}$ inhibits the endocrine-gonadal response to $17,20 \beta$-P, but neither the mechanism nor the biological function of this effect is known (Stacey, 2003). The increase in androgen receptor transcripts may be involved in the inhibitory pathway for $17,20 \beta$-P function.

In conclusion, experimental data linked a specific pheromone molecule $\left(\mathrm{PGF}_{2 \alpha}\right)$ released by female goldfish to neurogenesis in the diencephalon of adult male goldfish. This result suggests that an enriched chemical environment may promote adult neurogenesis. Another pheromone molecule released by female goldfish, 17,20 $\beta$-P, increased plasma $\mathrm{AD}$ in male goldfish via $\mathrm{GnRH}$ independent pathways, but increased female AR mRNA in the cerebellum via cGnRH-II-associated pathways. Chemical communication in goldfish is therefore sexually dimorphic and forms an intricate network involving structural reorganization of neural circuits and several neuroendocrine systems.

\section{References}

Alaux C, Robinson GE (2007) Alarm pheromone induces immediate-early gene expression and slow behavioral response in honey bees. J Chem Ecol 33:1346-1350.

Altman J, Das GD (1965) Autoradiographic and histological evidence of postnatal hippocampal neurogenesis in rats. J Comp Neurol 124:319-335.

Alvarez-Buylla A, Kirn JR (1997) Birth, migration, incorporation, and death of vocal control neurons in adult songbirds. J Neurosci 33:585-601.

Ambrogini P, Cuppini R, Cuppini C, Ciaroni S, Cecchini T, Ferri P, Sartini S, Del Grande P (2000) Spatial learning affects immature granule cell survival in adult rat dentate gyrus. Neurosci Lett 286:21-24.

Atema J, Holl K, Ikehara W (1980) Olfactory responses of yellowfin tuna (Thunnus albacares) to prey odors: chemical search image. J Chem Ecol 6:457-465.

Barnea A, Nottebohm F (1994) Seasonal recruitment of hippocampal neu- 
rons in adult free-ranging black-capped chickadees. Proc Natl Acad Sci U S A 91:11217-11221.

Barnea A, Nottebohm F (1996) Recruitment and replacement of hippocampal neurons in young and adult chickadees: an addition to the theory of hippocampal learning. Proc Natl Acad Sci U S A 93:714-718.

Beggs KT, Glendining KA, Marechal NM, Vergoz V, Nakamura I, Slessor KN, Mercer AR (2007) Queen pheromone modulates brain dopamine function in worker honey bees. Proc Natl Acad Sci U S A 104:2460-2464.

Carr WE (1982) Chemical stimulation of feeding behavior. In: Chemoreception in fishes (Hara TJ, ed), pp 259-273. Amsterdam: Elsevier.

Cayre M, Malaterre J, Scotto-Lomassese S, Strambi C, Strambi A (2002) The common properties of neurogenesis in the adult brain: from invertebrates to vertebrates. Comp Biochem Physiol B Biochem Mol Biol 132:1-15.

Chetverukhin VK, Polenov AL (1993) Ultrastructural radioautographic analysis of neurogenesis in the hypothalamus of the adult frog, Rana temporaria, with special reference to physiological regeneration of the preoptic nucleus. I. Ventricular zone cell proliferation. Cell Tissue Res 271:341-350.

Chung-Davidson YW, Bryan MB, Teeter J, Bedore CN, Li W (2008) Neuroendocrine and behavioral responses to weak electric fields in adult sea lampreys (Petromyzon marinus). Horm Behav 54:34-40.

Conover JC, Doetsch F, Garcia-Verdugo JM, Gale NW, Yancopoulos GD, Alvarez-Buylla A (2000) Disruption of Eph/ephrin signaling affects migration and proliferation in the adult subventricular zone. Nat Neurosci 3:1091-1097.

Dulka JG, Stacey NE, Sorensen PW, van der Kraak GJ (1987) A steroid sex pheromone synchronizes male-female spawning readiness in goldfish. Nature 325:251-253.

Fahrbach SE, Strande JL, Robinson GE (1995) Neurogenesis is absent in the brains of adult honey bees and does not explain behavioral neuroplasticity. Neurosci Lett 197:145-148.

Font E, Desfilis E, Pérez-Cañellas M, Alcántara S, García-Verdugo JM (1997) 3-Acetylpyridine-induced degeneration and regeneration in the adult lizard brain: a qualitative and quantitative analysis. Brain Res 754:245-259.

Fraser EJ, Stacey NE (2002) Isolation increases milt production in goldfish. J Exp Zool 293:511-524.

García-Verdugo JM, Doetsch F, Wichterle H, Lim DA, Alvarez-Buylla A (1998) Architecture and cell types of the adult subventricular zone: in search of the stem cells. J Neurobiol 36:234-248.

Goldman SA (1997) Comparative strategies of subependymal neurogenesis in the adult forebrain. In: Isolation, characterization and utilization of CNS stem cells (Gage FH, Christen Y, eds), pp 43-66. Berlin: Springer.

Goldman SA (1998) Adult neurogenesis: from canaries to the clinic. J Neurobiol 36:267-286.

Gould E, Beylin A, Tanapat P, Reeves A, Shors TJ (1999) Learning enhances adult neurogenesis in the hippocampal formation. Nat Neurosci 2:260-265.

Gronenberg W, Heeren S, Hölldobler B (1996) Age-dependent and taskrelated morphological changes in the brain and the mushroom bodies of the ant Camponotus floridanus. J Exp Biol 199:2011-2019.

Grozinger CM, Robinson GE (2007) Endocrine modulation of a pheromone-responsive gene in the honey bee brain. J Comp Physiol A Neuroethol Sens Neural Behav Physiol 193:461-470.

Grozinger CM, Sharabash NM, Whitfield CW, Robinson GE (2003) Pheromone-mediated gene expression in the honey bee brain. Proc Natl Acad Sci U S A 100:14519-14525.

Grozinger CM, Fischer P, Hampton JE (2007) Uncoupling primer and releaser responses to pheromone in honey bees. Naturwissenschaften 94:375-379.

Hara TJ, MacDonald S, Evans RE, Marui T, Arai S (1984) Morpholin, bile acids and skin mucus as possible chemical cues in salmonid homing: electrophysiological re-evaluation. In: Mechanisms of migration in fishes (McCleave JD, Arnold GP, Dodson JJ, Neill WH, eds), pp 363-378. New York: Plenum.

Harzsch S, Miller J, Benton J, Beltz B (1999) From embryo to adult: persistent neurogenesis and apoptotic cell death shape the lobster deutocerebrum. J Neurosci 19:3472-3485.

Kempermann G, Kuhn HG, Gage FH (1997) More hippocampal neurons in adult mice living in an enriched environment. Nature 386:493-495.

Kempermann G, Kuhn HG, Gage FH (1998) Experience-induced neurogenesis in the senescent dentate gyrus. J Neurosci 18:3206-3212.

Kobayashi M, Aida K, Hanyu I (1986) Pheromone from ovulatory female goldfish induces gonadotropin surge in males. Gen Comp Endocrinol 63:451-455.

Kobayashi M, Aida K, Hanyu I (1989) Induction of gonadotropin surge by steroid hormone implantation in ovariectomized and sexually regressed female goldfish. Gen Comp Endocrinol 73:469-476.

Kobayashi M, Sorensen PW, Stacey NE (2002) Hormonal and pheromonal control of spawning behavior in the goldfish. Fish Physiol Biochem 26:71-84.

Lim DA, Tramontin AD, Trevejo JM, Herrera DG, García-Verdugo JM, Alvarez-Buylla A (2000) Noggin antagonizes BMP signaling to create a niche for adult neurogenesis. Neuron 28:713-726.

López-García C, Molowny A, García-Verdugo JM, Ferrer I (1988) Delayed postnatal neurogenesis in the cerebral cortex of lizards. Dev Brain Res 43:167-174.

López-García C, Molowny A, García-Verdugo JM, Pérez-Sánchez F, Martínez-Guijarro FJ (1990) Postnatal neurogenesis in the brain of the lizard Podarcis hispanica. In: The forebrain in nonmammals: new aspects of structure and development (Schwerdtfeger WK, Germroth P, eds), pp 103-117. Berlin: Springer.

Luskin MB (1998) Neuroblasts of the postnatal mammalian forebrain: their phenotype and fate. J Neurobiol 36:221-233.

Mak GK, Enwere EK, Gregg C, Pakarainen T, Poutanen M, Huhtaniemi I, Weiss S (2007) Male pheromone-stimulated neurogenesis in the adult female brain: possible role in mating behavior. Nat Neurosci 10:1003-1011.

Nottebohm F (1985) Neuronal replacement in adulthood. Ann N Y Acad Sci 457:143-161.

Nottebohm F (1989) From bird song to neurogenesis. Sci Am 260:74-79.

Olson AK, Eadie BD, Ernst C, Christie BR (2006) Environmental enrichment and voluntary exercise massively increase neurogenesis in the adult hippocampus via dissociable pathways. Hippocampus 16:250-260.

Parhar IS (2002) Cell migration and evolutionary significance of GnRH subtypes. Prog Brain Res 141:3-17.

Partridge BL, Liley NR, Stacey NE (1976) The role of pheromones in the sexual behavior of the goldfish. Anim Behav 24:291-299.

Patel SN, Clayton NS, Krebs JR (1997) Spatial learning induces neurogenesis in the avian brain. Behav Brain Res 89:115-128.

Pérez-Cañellas MM, García-Verdugo JM (1996) Adult neurogenesis in the telencephalon of a lizard: a $\left[{ }^{3} \mathrm{H}\right]$ thymidine autoradiographic and bromodeoxyuridine immunocytochemical study. Brain Res Dev Brain Res 93:49-61.

Pérez-Cañellas MM, Font E, García-Verdugo JM (1997) Postnatal neurogenesis in the telencephalon of turtles: evidence for nonradial migration of new neurons from distant proliferative ventricular zones to the olfactory bulbs. Brain Res Dev Brain Res 101:125-137.

Polenov AL, Chetverukhin VK (1993) Ultrastructural radioautographic analysis of neurogenesis in the hypothalamus of the adult frog, Rana temporaria, with special reference to physiological regeneration of the preoptic nucleus. II. Types of neuronal cells produced. Cell Tissue Res 271:351-362.

Poling KR, Fraser EJ, Sorensen PW (2001) The three steroidal components of the goldfish preovulatory pheromone signal evoke different behaviors in males. Comp Biochem Physiol B Biochem Mol Biol 129:645-651.

Ramirez C, Nacher J, Molowny A, Sanchez-Sanchez F, Irurzun A, LopezGarcia C (1997) Photoperiod-temperature and neuroblast proliferation-migration in the adult lizard cortex. Neuroreport 8:2337-2442.

Rees CB, Li W (2004) Development and application of a real-time quantitative PCR assay for determining CYP1A transcripts in three genera of salmonids. Aquat Toxicol 66:357-368.

Saglio P, Fauconneau B (1985) Free amino acid content in the skin mucus of goldfish, Carassius auratus L.: influence of feeding. Comp Biochem Physiol A Comp Physiol 82:67-70.

Sandeman R, Sandeman D (2000) Impoverished and enriched living conditions influence the proliferation and survival of neurons in crayfish brain. J Neurobiol 45:215-226.

Scherwood NM, Von Schalburg K, Lescheid DW (1997) Origin and evolution of GnRH in vertebrates. In: GnRH neurons: gene to behavior (Parhar IS, Sakuma Y, eds), pp 3-25. Tokyo: Brain Shuppan.

Scott AP, Sorensen PW (1994) Time-course of release of pheromonally active gonadal steroids and their conjugates by ovulatory goldfish. Gen Comp Endocrinol 96:309-323. 
Scott AP, Bye VJ, Baynes SM (1980) Seasonal variations in sex steroids of female rainbow trout (Salmo gairdnerii Richardson). J Fish Biol 17:587-592.

Scotto Lomassese S, Strambi C, Strambi A, Charpin P, Augier R, Aouane A, Cayre M (2000) Influence of environmental stimulation on neurogenesis in the adult insect brain. J Neurobiol 45:162-171.

Sorensen PW, Goetz FW (1993) Pheromonal and reproductive function of $\mathrm{F}$ prostaglandins and their metabolites in teleost fish. J Lipid Med 6:385-393.

Sorensen PW, Hara TJ, Stacey NE, Goetz FW (1988) F prostaglandins function as potent olfactory stimulants that comprise the postovulatory female sex pheromone in goldfish. Biol Reprod 39:1039-1050.

Sorensen PW, Stacey NE, Chamberlain KJ (1989) Differing behavioral and endocrionological effects of two female sex pheromones on male goldfish. Horm Behav 23:317-332.

Sorensen PW, Hara TJ, Stacey NE, Dulka JG (1990) Extreme olfactory specificity of the male goldfish to the preovulatory steroidal pheromone $17 \alpha, 20 \beta$-dihydroxy-4-pregnen-3-one. J Comp Physiol A Neuroethol Sens Neural Behav Physiol 166:373-384.

Sorensen PW, Pinillos M, Scott AP (2005) Sexually mature male goldfish release large quantities of androstenedione into the water where it functions as a pheromone. Gen Comp Endocrinol 140:164-175.

Stacey NE (1987) Roles of hormones and pheromones in fish reproductive behavior. In: Psychobiology of reproductive behavior, an evolutionary perspective (Crews D, ed), pp 28 - 60. Englewood Cliffs, NJ: Prentice Hall.

Stacey NE (1991) Hormonal pheromones in fish: status and prospects. In: Proceedings of the Fourth International Symposium on the Reproductive Physiology of Fish (Scott AP, Sumpter JP, Kime DS, Rolfe MS, eds), pp 177-181. Sheffield, UK: Fish Symposium 91.

Stacey NE (2003) Hormones, pheromones and reproductive behavior. Fish Physiol Biochem 28:229-235.

Stacey NE, Peter RE (1979) Central action of prostaglandins in spawning behavior of female goldfish. Physiol Behav 22:1191-1196.

Stacey NE, Sorensen PW (1986) 17 $\alpha, 20 \beta$-Dihydroxy-4-pregnen-3-one: a steroidal primer pheromone which increases milt volume in the goldfish, Carassius auratus. Can J Zool 64:2412-2417.

Stacey NE, Sorensen PW (2002) Fish hormonal pheromones. In: Hormones, brain, and behavior, Vol 2 (Pfaff D, Arnold D, Ategen A, Farbach S, Rubin R, eds), pp 375-435. New York: Academic.

Stacey NE, Fraser EJ, Sorensen PW, Van Der Kraak GJ (2001) Milt production in goldfish: regulation by multiple social stimuli. Comp Biochem Physiol C Toxicol Pharmacol 130:467-476.

Tramontin AD, Brenowitz EA (2000) Seasonal plasticity in the adult brain Trends Neurosci 23:251-258.

van Praag H, Kempermann G, Gage FH (1999a) Running increases cell proliferation and neurogenesis in the adult mouse dentate gyrus. Nat Neurosci 2:266-270.

van Praag H, Christie BR, Sejnowski TJ, Gage FH (1999b) Running enhances neurogenesis, learning, and long-term potentiation in mice. Proc Natl Acad Sci U S A 96:13427-13431.

Vergoz V, Schreurs HA, Mercer AR (2007) Queen pheromone blocks aversive learning in young worker bees. Science 317:384-386.

Volkoff H, Peter RE (1999) Actions of two forms of gonadotropin releasing hormone and a GnRH antagonist on spawning behavior of the goldfish (Carassius auratus). Gen Comp Endocrinol 116:347-355.

Yu KL, Lin X-W, Bastos JC, Peter RE (1997) Neural regulation of GnRH in teleost fishes. In: GnRH neurons: gene to behavior (Parhar IS, Sakuma Y, eds), pp 277-312. Tokyo: Brain Shuppan.

Zheng W, Stacey NE (1996) Two mechanisms for increasing milt volume in male goldfish. J Exp Zool 276:287-295.

Zheng W, Stacey NE (1997) A steroidal pheromone and spawning stimuli act via different neuroendocrine mechanisms to increase gonadotropin and milt volume in male goldfish (Carassius auratus). Gen Comp Endocrinol 105:228-238.

Zupanc GKH (2006) Neurogenesis and neuronal regeneration in the adult fish brain. J Comp Physiol A Neuroethol Sens Neural Behav Physiol 192: 649-670. 